mick's "Editors Today" draws a good picture but loads the volume a bit in the direction of editorship.

The reading of these studies raises the hope that equally capable speakers will continue the series with other topics deserving coverage, such as book distribution, censorship, book design, bestseller developments, and book production: machines and techniques. Impatient readers looking forward to the collection of the next seventeen lectures to appear a quarter of a century hence are reminded of the annual printings in pamphlet format.-Frank L. Schick, Wayne State University Library.

\section{Russian Transliteration}

Transkriptionsprobleme; die korrekte Wiedergabe russischer Namen im Deutschen, [von ] Günter Mühlpfordt. Berlin: Rütten \& Loening, 1957. 175p.

Joining a long procession of librarians, translators, and teachers of Russian, Günter Mühlpfordt deals with the problem of Russian transliteration in Germany. He deplores the lack of uniformity in transliterating Russian on the part of publishers, particularly in journals, and some of the ludicrous forms of transliterated Russian names which occur in German publications (e.g., Pjerjewjersjew, which in ordinary English transliteration would be Pereverzev). After describing the Duden transcription developed by W. Steinitz as a unitary system for popular use, he points out its shortcomings. It does not, for example, lend itself to the restoration of the original Russian (retransliteration). Inaccuracies and confusion result, for example, for the use of $s s$ for intervocalic Russian $c$, of stsch for three different possible letters and letter combinations, and of some non-German letter combinations (sh for the sound represented by the French $j$ ).

In place of the Duden transcription Mühlpfordt offers for scholarly and library purposes a "scientific," or library, transliteration, which meets the objections to the "popular" one. To users of English the following elements of this system are of particular interest, principally because they correspond to English transliteration: $v$ instead of $w$; the prime '. as in English transliterations, instead of the $j ; z$ instead of intervocalic $s$.
On the other hand the use of $c$ in the "scientific" transliteration for the Russian letter usually transliterated in English by $t s$ or $t z$ would lead to confusion when $c$ occurs before $a, o, u$, or a consonant. The use of $z$, $\ddot{c}, \tilde{s}$, and $\ddot{s} \dot{c}$ is open to the same objections as Mühlpfordt expresses in regard to $s h$ for the letter which is rendered in French by $j$ (in English usually by $z h$ ): they are not distinguishable by most Germans from $z, c, s$, and $s c$. His position represents essentially the desire for an international, or universal, transliteration of the Cyrillic alphabet, which has been attempted by many, including the International Federation for Documentation, without appreciable success.

Most of the book-eighty-nine pages of it-is devoted to an aspect of transcription which is transliteration only in a limited sense. It includes: a list of retranscribed names of non-Russians-Germans, Englishmen, Frenchmen, and Italians-which occur in the works of Marx and Engels; a table of letter-equivalents by which such retranscription may be achieved; and a list of personal, geographic and ethnic names, and some common nouns, which occur in the text with their transcription according to both the Duden and library systems. These retranscription tables are a wilderness which would as often yield several variables as guide the user straight to his goal.

The principal value of the work to English-speaking transliterators of Russian is in the variety of problems it presents and of the examples it cites. This feature of the book may well lead to a thorough examination of the problems of transliteration of Russian for English-speaking users and to research resulting in lists of names of West Europeans in Russian accompanied by their vernacular forms-David J. Haykin, Library of Congress.

\section{English Common Reader}

The English Common Reader; a Social History of the Mass Reading Public 18001900. By Richard D. Altick. Chicago: University of Chicago Press [c1957]. 430p. \$6.

If you think that "railway literature" has something to do with timetables, that "number-men" are bookies and that Confidential invented the idea of peeking into other peo- 
ple's boudoirs, you had better go out and buy a copy of Richard Altick's The English Common Reader. Here is a lively socioeconomic history depicting the reading Englishman as mirrored in public and adult education; commercial, proprietary, and public circulating libraries; and the publishing of books, periodicals and newspapers.

The author of The Scholar Adventurers is clever enough to know that "pages of statistics could be copied . . . but the effect would be more numbing than illuminating." Therefore, you will find The English Common Reader brimming with anecdote but only spiced with figures. Still, there is an impressive amount of factual documentation presented with the moderation and good sense of the mature scholar, who knows full well that one can't swallow whole every figure ever set on paper. If the work at hand lacks the glamour and intense interest of The Scholar Adventurers, it is still a firstrate job in a much more complex and difficult field.

If we define the English common reader in terms of the working masses, he did not exist in great numbers until about 1850 . The means to secure the necessary education and the economic resources to buy and read the printed word were restricted to the rich until approximately 1800 , but the instruments of dissemination of popular literature began to function much earlier. John Wesley was a great "transformer" for public consumption of such works as Pilgrim's Progress and Paradise Lost, and the Methodist Book Room in London of 1740 played an important role in distributing easily read, if moralistic, tracts. Well-to-do women constituted a ready market for Pamela, thereby heralding fiction as one of the single most powerful lures to reading among the masses. The Sunday School movement of the late eighteenth century also spread the means, and inspired the desire, for reading.

Fighting a losing battle against this popularization of reading was a government that feared the proliferation of Jacobin sentiments if the common man learned to absorb such disturbing treatises as The Rights of Man (1,500,000 copies in seventeen years) and Cobbett's Political Register. For decades, the specter of reading among the masses evoked an intriguing, not to say paradoxial, ambivalence among moralists and government officials. A Royal Proclamation of 1792 -by no means the first of its kind-was issued against "divers wicked and seditious writings," and many a purveyor of Jacobin writing suffered fines or arrest as a result. Tax supported libraries were denounced on the grounds that the public at large might as logically be expected to support pubs and games as reading, and as late as 1887 , only two parishes in London had rate-supported libraries. However, imbued with the doctrine of the perfectibility of man, some segments of the governing class were inspired to believe that free libraries were the answer to all social problems including those of drink and juvenile delinquency. In this maelstrom of conflicting opinion and amidst the class strife of late eighteenth and early nineteenth-century England, Hannah More issued her deceptively moral tracts; censorship of classics was achieved through bowdlerization and "elegant" extracts; and mechanics institutes first attracted, then alienated, working men by offering them a heavy diet of utilitarianism through institute-supported libraries and through soporific lectures at the end of a long day's toil.

A fascinating analysis of book, periodical, and newspaper costs from the 1770's on helps to explain the painfully slow steps by which reading matter became widely available to the masses. In 1774 a book cost as much as a good pair of breeches, a pamphlet as much as a month's supply of candles. Well into the nineteenth century, publishing was a closed circle which delighted in sumptuous limited editions. Ivanhoe (1820) originally sold for the unheard-of price of $30 \mathrm{~s}$, and as late as 1835 the 5 s required for a reprinted novel would buy ten pounds of meat. Lack of mechanization, the absence of an enterprising spirit, the ineffectiveness of popular education and illogical taxes on paper, newspapers and even on the number of windows in houses conspired to discourage the reading habit and impeded the diffusion of the printed word.

Even so, other countervailing forces were fermenting within the depths of English society. As early as 1661 , booksellers had rented books in the spirit of later commercial circulating libraries. This practice became a potent force under men like Charles Ed- 
ward Mudie, who was such a dominating factor in the trade that he literally dictated the character of the publications he distributed. The 1830's saw the rise of the cheap reprint in both books and periodicals, and fortunes, not always respectable, were made in the discovery of the mass market, for there were men like the unscrupulous Thomas Tegg whose idea of editing was pretty rough and ready, even to the extent of chopping off classics like Paradise Lost at the point where he ran out of paper. And there was Thomas Kelley, the number-man, that is, a man who issued reprints in parts or numbers, who made a fortune and become Lord Mayor of London. He and his colleagues foreshadowed Hollywood by exaggerated descriptions of works as "superb" and "magnificent" and by dressing up ordinary texts with fancy title pages and illustrations only to have these frills fade away as the series progressed. Nevertheless, the impecunious family, with questionable economy, found it possible to buy expensive works in parts rather than to lay out the large (but lesser) lump sum necessary for a single volume.

The religious struggle for the minds and spirits, not to say the souls and bodies of men, was everywhere manifest in the nineteenth century, closing in a blaze of glory when, in 1897, the Religious Tract Society alone distributed $38,720,000$ copies of literature, almost half of which was books. But to the despair of many a well-placed official, the masses were induced to read, not only by pious tracts and utilitarian pamphlets but also by penny dreadfuls, epitomized by Black Bess, which ran 2,067 pages in five years before burgeoning into a sequel; by Gothic novels from the pens of Monk Lewis and Clara Reeve; and by salacious books and magazines as well as by sensational newspaper stories of murder, sex, wars, and catastrophes. Many a librarian will find solace in the fact that nineteenth century newspaper reading rooms, like their later counterparts, were graced by the racing enthusiast who developed "systems," made daily selections and even placed bets in the library, thereby goading some librarians to obliterate the racing news from each issue, a grievous but perhaps justifiable step.

Newspapers staggered for years under a heavy stamp tax which drove single issues

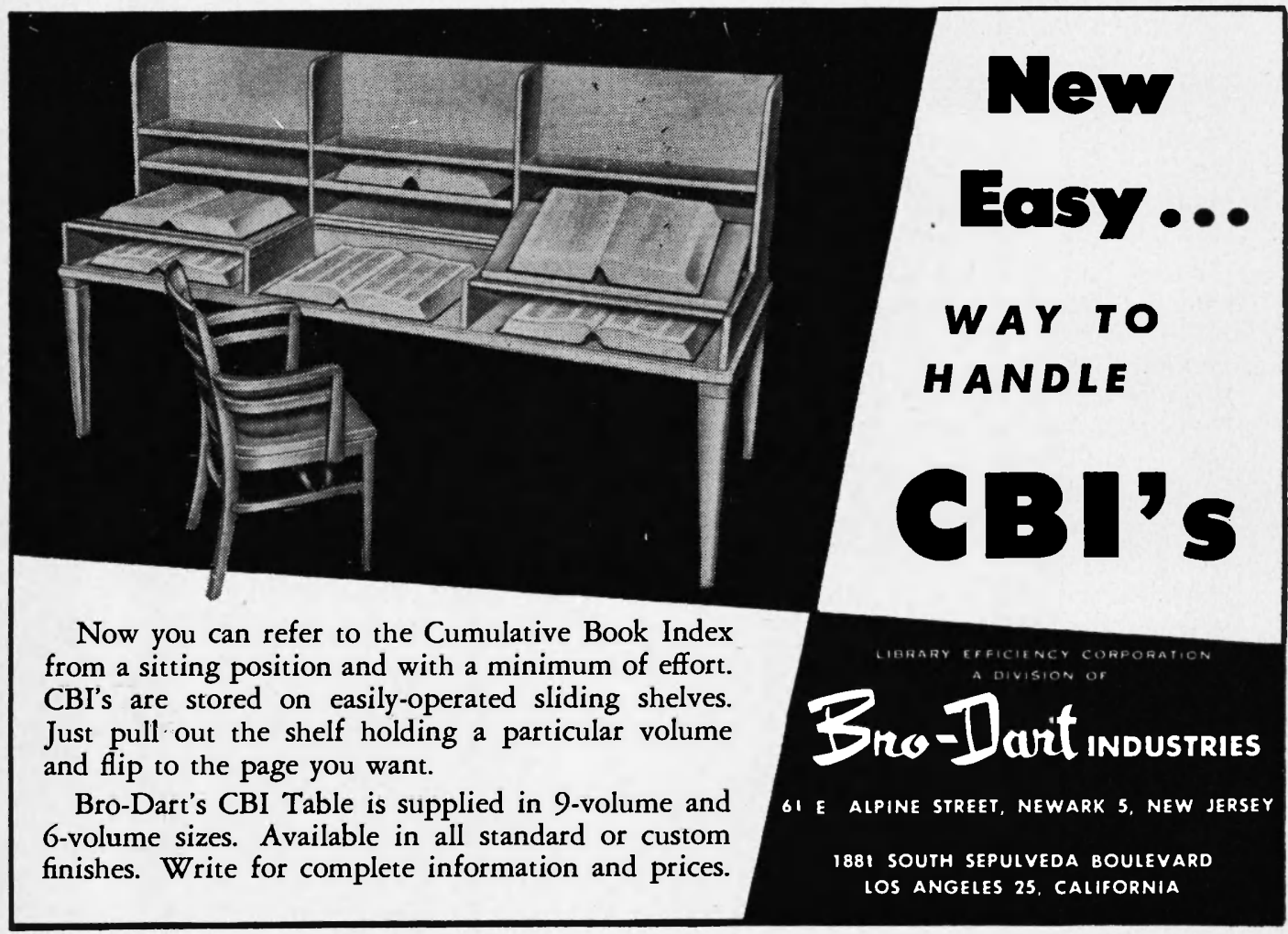

Please mention $C$ \& $R L$ when corresponding with its advertisers. 
up to $6 \mathrm{~d}$. In 1800 , the Times sold less than 5,000 copies a day which was not necessarily an indication of the impact of this medium, since newspapers were passed through many hands, were read in coffee shops, and were even rented prior to final sale. The hated and evaded stamp tax was repealed in 1861 and by 1882 the Times had a circulation of 100,000 .

Perhaps Dr. Johnson was right when he said "People in general do not willingly read, if they can have any thing else to amuse them," but The English Common Reader provides an exciting account of how reading came to the masses in England, and there is reason to believe that the thirst for knowledge and information, the desire to know on the part of the common man, will continue to find fulfillment in the printed word in a tradition that has been evolving for centuries.-Rutherford D. Rogers, Library of Congress.

\section{Classified Advertisements}

Rate: \$1 per line; 3-line minimum. Closes first of month of date of issue.

\section{CHEMICAL TRANSLATING}

Service, 881 Lytton, Palo Alto, Calif. Authoritative translations from all European languages, $\$ 15-\$ 18 / 1000$ words; Oriental, $\$ 20$.

Building Special Collections is one of our specialties. Foreign books and periodicals, current and out of print. Albert J. Phiebig, Box 352, White Plains, N.Y.

\section{OUT-OF-PRINT BOOKS}

BA.RNES \& Noble, Inc. supplies books not obtainable from publishers immediately from stock of over a million volumes or in reasonably quick time through free Search Service. Send lists to Dept. CR, Barnes \& Noble, Inc., 105 Fifth Ave., New York 3, N.Y.

Assistant Librarian position available at U.S. Military Academy Library. Males preferred. Starting salary $\$ 6,390$. Baccalaureate and MLS degree with 3 years supervisory experience required. Apply Civilian Personnel Officer, U.S. Military Academy, West Point, New York.

UNIVERSITY OF ILLINOIS, Library of Medical Sciences, Chicago, has two openings: (1) Serials Librarian, minimum salary $\$ 5,500$, experience necessary, may be in other than a medical library; (2) Catalog Assistant, salary $\$ 4,500$, experience not necessary. Fifth year Library School degree, 1 month's vacation, retirement system, academic rank. Write: Wilma Troxel, Librarian, University of Illinois, Library of Medical Sciences, 1853 West Polk Street, Chicago 12, Illinois.
EdITORIAL OpPoRTUNITY: Young man or career woman qualified to abstract chemical and mechanical engineering literature and be trained as assistant editor of monthly abstract journal. Must type. Pleasant working conditions, competitive salary, benefits, opportunity for undergraduate or graduate study at Illinois Tech. Information Service, Institute of Gas Technology, Chicago 16.

Colonial Book Service-Specialists in supplying the out-of-print books as listed in all library indices (Granger Poetry; Essay and General Literature; Shaw; Standard; Fiction; Biography; Lamont; Speech; etc.) Want lists invited. 23 East 4th St., New York 3, N.Y.

Stanley Gilman, American History, Newspaper History and Out of Print Books. Box 131, Cooper Station, New York 3, N.Y.

Cataloger, experience with serials work in college or research library desired. Salary open, depending upon qualifications. Month's vacation, retirement plan, hospitalization, liberal sick leave. Beautiful air-conditioned building. Write to Librarian, Fondren Library, Rice Institute, Houston, Texas.

Rensselaer Poly Inst. Libraries; Position Serials Librarian-immediate appointment. $\$ 4,000-\$ 5,000$ range in $\$ 250$ increments. L.S. degree. Social Security and Retirement-Insurance program. Please send qualifications, references and photo. Apply. Edw. A. Chapman, Director RPI Libraries, Troy, N.Y.

Please mention $C$ \& $R L$ when corresponding with its advertisers. 